\title{
Deoxyribonucleic Acid Hybridization Among Selected Leptospiral Serotypes
}

\author{
J. J. BRENDLE, M. ROGUL, and A. D. ALEXANDER \\ Walter Reed Army Institute of Research, \\ Walter Reed Army Medical Center, \\ Washington, D. C. 20012
}

\begin{abstract}
The deoxyribonucleic acids (DNA) from phenotypically unusual Leptospira strains were compared to each other and to reference strains of existing genetic groups. In the "pathogenic" genetic complex, three groups emerged as genetically distinct. Representative examples of these groups were bataviae strain Van Tienen, javanica strain Veldrat Bataviae, and ranarum strain Iowa City Frog. The serologically different muenchen strain Muenchen 90C, icterohaemorrhagiae strain RGA, and kabura strain Kabura were found to be closely related to bataviae strain Van Tienen. The "saprophytic"genetic complex also contained three inter-related groups. The representative examples were patoc strain Patoc I, codice strain CDC, and Turtle strain A-183. Strain 3055 of serotype illini appeared to have unique nucleotide sequences and was placed in a third genetic complex of its own. Partial relatedness between DNA could be emphasized by increasing the salt concentrations in the incubation media. This could not be attributed to the methods of annealing but appeared to be dependent upon the genetic relatedness between the heterologous DNA.
\end{abstract}

The genus Leptospira can be separated into two major divisions, the pathogenic and the so-called "saprophytic" or "biflexa" leptospiras. The latter are usually found in fresh surface waters and are rarely found in animals. In addition to infectivity, various phenotypic properties serve to separate members of the two divisions (18). Using deoxyribonucleic acid (DNA) base composition determinations and specific DNA-DNA annealing tests in agar matrices, Haapala et al. (7) demonstrated genetic differences between, as well as within, serotypes in the two divisions. Two distinct genetic groups were demonstrated among selected strains within each of the pathogenic and biflexa serotypes. The serological relationships among leptospiras did not necessarily denote genetic relatedness; however, strains of the same or very similar serotypes appeared to be in the same genetic group. The two genetic groups of pathogenic leptospiras could be differentiated from each other and from the two biflexa groups by a number of phenotypic characteristics which also served as a basis for the leptospiral groups described by Johnson and Harris (9). The principal differentiating attributes were lipase production and relative resistance to the bacteriostatic action of 8-azaguanine (AZA) and 2,6-diaminopurine (DAP).
The genetic groups of pathogenic strains represented by strains of serotypes bataviae and javanica corresponded to the Johnson and Harris biological groups 1 and 2, respectively. Group 1 strains were sensitive to AZA and DAP and had lipase activity, whereas group 2 strains were sensitive to $\mathrm{AZA}$, resistant to $\mathrm{DAP}$, and lacked lipase activity. The two genetic groups of biflexa strains were phenotypically indistinguishable and fit into the Johnson and Harris biological group 3 , which was characterized by resistance to both purine analogues and by positive lipase activity.

The purpose of this report is to decipher genetic interrelationships of representative strains within the four genetic groups and among additional phenotypically distinct strains of leptospiras. (This work was presented in part at the International Symposium on Leptospiroses, Bratislava-Smolenice, Czechoslovakia, 11-13 September 1973.)

\section{MATERIALS AND METHODS}

Bacterial strains. Van Tienen (serotype bataviae) and Veldrat Bataviae 46 (serotype javanica) are representative strains of the genetic groups of pathogenic leptospiras; Patoc I (serotype patoc) and the CDC strain of serotype codice (11) are representative 
of the two genetic groups of biflexa strains (9). Pathogenic leptospiral strains Kabura (serotype $k a$ bura) and Muenchen C90 (serotype muenchen) were selected because they did not fit into the biological groups described by Johnson, and Harris (9). Strain Kabura was sensitive to both AZA and DAP and lacked lipase activity (9). Strain Muenchen C90 was resistant to DAP, sensitive to $A Z A$, and had lipase activity (R. Johnson, personal communication).

Two amphibian isolates, Iowa City Frog (serotype ranarum) and Turtle A-183 (serotype undetermined), were included because of their unique host origin and possession of attributes characteristic of both pathogenic and saprophytic leptospiras. The Iowa City Frog strain was originally isolated from pooled kidneys of frogs $(4,5)$. It behaved like a pathogen in its relative susceptibility to $\mathrm{AZA}, \mathrm{CuSO}_{4}$, and $\mathrm{NaHCO}_{3}$ (2) and in its serological affinity with a pathogenic leptospira strain, 267-1348, isolated in Malaysia (unpublished data); however, the strain was serologically distinct and was classified as a new serotype, ranarum, by Babudieri (1). The frog strain resembled biflexa strains in its ability to multiply at low temperatures (5) and its inability to establish infection in laboratory animals $(1,4)$. Strain Turtle A-183 was isolated from the cloaca of a turtle in an enzootic area of leptospirosis in Illinois (R. D. Andrews, Ph.D. Thesis, University of Illinois, Urbana, 1966). Its guanine plus cytosine content, $36.0 \%$, was suggestive of pathogenic leptospiras on the basis of previous work (7), but it had cultural and biochemical attributes of biflexa strains.

Strain 3055, isolated in 1965 from the urine of a bull in Illinois (Lyle Hanson, unpublished data), is unique in its ability to grow in ordinary Trypticase soy broth without the addition of serum or serum components (H. C. Ellinghausen, personal communication); it is also the only leptospira to have a phage associated with it (12). Like biflexa strains, its growth is uninhibited by relatively high concentrations of purine analogues and divalent copper ions. It also did not cause illness in calves or laboratory rodents (15). Strain 3055 was serologically distinct when tested against an array of 55 diverse serotype antisera from all known pathogenic serogroups. It was also unrelated to selected serologically distinct strains of biflexa. It has recently been identified as a new serotype and was designated serotype illini (16).

Strain RGA was included because of its historical importance as the oldest extant representative strain of $L$. interrogans, seroty pe icterohaemorrhagiae. Proteus mirabilis, an organism with a DNA nucleotide base ratio similar to that of leptospiral DNA but which is completely unrelated to the genus Leptospira, was used as the source of control DNA.

Cultural conditions. The identity of each culture was confirmed serologically by agglutination tests with specific antisera. All cultures were grown at $30 \mathrm{C}$ in modified Ellinghausen and McCullough albumin fatty acid broth (17). Cultures were harvested by centrifugation during the late logarithmic growth and examined for contaminating microorganisms by the use of appropriate cultural techniques and microscope examinations. Radioactive DNA was prepared by the addition of $0.25 \mathrm{mCi}$ of $\left[8-^{14} \mathrm{C}\right]$ adenine (54 to 58
$\mathrm{mCi} / \mathrm{mmol}$, Schwarz Mann, Orangeburg, N. J.) or 2.5 $\mathrm{mCi}$ of $\left[{ }^{3} \mathrm{H}\right]$ adenine $(\mathrm{G})(6.0 \mathrm{Ci} / \mathrm{mmol}$, New England Nuclear, Boston, Mass.) per liter of culture media prior to bacterial inoculation. After purification, the DNA were sheared and denatured by the method of Rogul et al. (13) and are henceforth designated as DNA*. The specific activities (counts per minute per microgram) of the DNA containing $\left[{ }^{3} \mathrm{H}\right]$ adenine were as follows: bataviae, 10,325; javanica, 8,522; patoc, 8,162 ; and codice, 18,681 . The specific activities of the DNA containing $\left[8-{ }^{14} \mathrm{C}\right]$ adenine were: ranarum, 52,992; A-183, 30,576; and illini, 19,985.

DNA extraction. The DNA extraction method of Marmur (10) was followed through the ribonuclease step. Subsequent purification followed the method of Rogul et al. (13). The purified DNA preparations were dissolved in 0.1 standard saline citrate $(\mathrm{SSC}=0.15 \mathrm{M}$ $\mathrm{NaCl}, 0.015 \mathrm{M}$ sodium citrate) and refrigerated until used.

Determination of base composition. The buoyant densities of the nucleic acids were determined by equilibrium density gradient centrifugation in $\mathrm{CsCl}$ solutions using a Spinco model E analytical ultracentrifuge. The buoyant densities were converted to percent nucleotide base composition expressed as percent guanine plus cy tosine $(G+C)$ by the method of Schildkraut et al. (14).

DNA binding on membrane filters. Annealing tests were performed by the method of Denhardt (3). The nucleic acids were denatured by heating to $100 \mathrm{C}$ in a $0.1 \times$ SSC solution for $10 \mathrm{~min}$ and quenching in an ice bath. Thirty micrograms of DNA was placed on 25-mm, 0.45- $\mu \mathrm{m}$ pore size membrane filters (MPF: Millipore Corp., Bedford, Mass.) by aspirating $5 \mathrm{ml}$ of $6 \times$ SSC containing the DNA through the filter. After drying the filters, annealing tests were carried out using the preincubation media of Denhardt containing $3 \times \mathrm{SSC}$ or $6 \times \mathrm{SSC}$. DNA* was added in a ratio of $1: 30$ to the amount of filter-immobilized DNA. After $16 \mathrm{~h}$ of incubation at $65 \mathrm{C}$, the filters were washed with $3 \times$ or $6 \times$ SSC and dried. From experiments performed with homologous and nonrelated DNA preparations, $65 \mathrm{C}$ was determined to be the optimum temperature for specific binding. The amount of radioactivity retained on each MPF was determined by scintillation counting. The scintillating fluid was a toluene solution containing $4 \mathrm{~g}$ of Omnifluor per liter (New England Nuclear, Boston, Mass.). Relatedness was calculated from the following equation: [(counts/ min retained on MPF in the heterologous reaction)/ (counts/min retained on MPF in the homologous reaction)] $\times 100=$ percentage of genetic relatedness.

DNA binding in agar. Quantitative DNA duplex formation in agar matrices was determined using a procedure similar to that of Rogul et al. (13). Approximately $0.3 \mathrm{~g}$ of agar containing $90 \mu \mathrm{g}$ of DNA were incubated with $3 \mu \mathrm{g}$ of DNA*. The DNA in $2 \times$, $3 \times$, or $6 \times$ SSC was annealed in small screw-capped vials for $16 \mathrm{~h}$ at $65 \mathrm{C}$. The contents of the vials were then transferred to thermally controlled, waterjacketed columns. Solutions of $2 \times, 3 \times$, or $6 \times$ SSC were used to wash unbound DNA* from the agar at 65 $\mathrm{C}$; the columns were then allowed to cool, and 2-ml washes of $0.1 \times$ SSC were used to elute the bound 
$\mathrm{DNA}^{*}$ as the temperature of the columns was raised from 50 to $75 \mathrm{C}$. The eluants were collected in scintillation vials, and the radioactivity was determined by scintillation counting in a toluene-Triton $\mathrm{x}-100(2: 1 \mathrm{vol} / \mathrm{vol})$ solution containing $4 \mathrm{~g}$ of Omnifluor per liter.

Relatedness was calculated from the following equation: [(total counts/min of bound DNA* eluted from the agar in the heterologous reaction)/(total counts/min of bound DNA* eluted from the agar in the homologous reaction)] $\times 100=$ percentage of genetic relatedness.

\section{RESULTS AND DISCUSSION}

DNA duplex formation on MPF. The annealing tests in a previous study (7) were done in an agar matrix prepared with double-strength standard saline citrate solution $(2 \times$ SSC). For the present studies, the Denhardt method (3) was first selected because it had considerable advantages over the agar matrix method in time and material requirements. In Denhardt's original publication, the final salt concentrations in the incubation media were difficult to determine because of the various methods of DNA denaturation employed. The final concentrations appeared to range from 3 to $6 \times \mathrm{SSC}$. Generally, $6 \times \mathrm{SSC}$ is considered desirable to retard the leaching of immobilized DNA from the filters $(2,6,8)$.

The results of annealing tests in $3 X$ and $6 X$ SSC are summarized in Table 1 . When complementary base sequences were compared,

TABLE 1. Comparative homology of leptospiral DNA in $3 \times$ and $6 \times$ SSC incubation solvents ${ }^{a}$

\begin{tabular}{|c|c|c|c|c|c|c|c|c|c|}
\hline \multirow[b]{3}{*}{ Complex } & \multirow{3}{*}{$\begin{array}{c}\text { Serotype } \\
\text { immobilized } \\
\text { DNA }\end{array}$} & \multicolumn{8}{|c|}{$\begin{array}{c}\text { Percent homology of reference DNA and incubation } \\
\text { solvent }\end{array}$} \\
\hline & & \multicolumn{2}{|c|}{ bataviae* } & \multicolumn{2}{|c|}{ javanica* } & \multicolumn{2}{|c|}{ patoc* } & \multicolumn{2}{|c|}{ codice* $^{*}$} \\
\hline & & $\begin{array}{l}3 \times \\
\text { SSC }\end{array}$ & $\begin{array}{l}6 \times \\
\text { SSC }\end{array}$ & $\begin{array}{l}3 \times \\
\text { SSC }\end{array}$ & $\begin{array}{l}6 \times \\
\text { SSC }\end{array}$ & $\begin{array}{l}3 \times \\
\text { SSC }\end{array}$ & $\begin{array}{l}6 \times \\
\text { SSC }\end{array}$ & $\begin{array}{l}3 \times \\
\text { SSC }\end{array}$ & $\begin{array}{l}6 \times \\
\text { SSC }\end{array}$ \\
\hline \multirow[t]{6}{*}{ "Pathogens" } & bataviae & 100 & 100 & 35.2 & 50.8 & 10.2 & 4.8 & 8.4 & 8.0 \\
\hline & muenchen & 99.0 & 97.5 & 34.7 & 62.6 & 8.9 & 4.7 & 12.2 & 6.2 \\
\hline & icterohaemorrhagiae & 92.6 & 80.0 & 29.9 & 51.4 & 9.4 & 4.1 & 5.1 & 6.6 \\
\hline & kabura & 71.0 & 75.5 & 28.3 & 54.6 & 9.1 & 4.9 & 7.3 & 8.1 \\
\hline & javanica & 41.7 & 48.8 & 100 & 100 & 8.9 & 4.0 & 6.6 & 5.3 \\
\hline & ranarum & 31.9 & 45.3 & 39.8 & 55.3 & 10.6 & 4.1 & 6.3 & 6.6 \\
\hline \multirow[t]{3}{*}{ "Saprophytes" } & patoc & 7.3 & 4.8 & 3.0 & 5.7 & 100 & 100 & 35.7 & 66.9 \\
\hline & codice & 4.6 & 8.7 & 3.1 & 6.7 & 29.0 & 42.7 & 100 & 100 \\
\hline & Turtle (A-183) & 8.7 & 8.0 & 5.7 & 5.8 & 35.6 & 32.8 & 59.1 & 54.4 \\
\hline New & illini & 2.8 & 1.6 & 4.9 & 1.4 & 2.6 & 1.7 & 1.7 & 1.7 \\
\hline $\begin{array}{l}\text { Control (Proteus } \\
\text { mirabilis) }\end{array}$ & & 3.6 & 2.9 & 1.8 & 1.6 & 4.6 & 1.9 & 3.3 & 2.4 \\
\hline
\end{tabular}

${ }^{a}$ Annealing performed on MPF.

TABLE 2. Comparative homology of leptospiral DNA by different methods

\begin{tabular}{|c|c|c|c|c|c|c|c|}
\hline \multirow[b]{3}{*}{ Complex } & \multirow{3}{*}{$\begin{array}{c}\text { Serotype } \\
\text { immobilized } \\
\text { DNA }\end{array}$} & \multicolumn{6}{|c|}{ Percent homology of reference DNA and incubation matrix } \\
\hline & & \multicolumn{3}{|c|}{ bataviae* } & \multicolumn{3}{|c|}{ patoc* } \\
\hline & & $\underset{2 \times \mathrm{SSC}^{a}}{\operatorname{Agar}}$ & $\begin{array}{c}\text { MPF } \\
3 \times \text { SSC }\end{array}$ & $\begin{array}{c}\text { MPF } \\
6 \times \text { SSC }\end{array}$ & $\underset{2 \times \text { SSC }^{a}}{\text { Agar }}$ & $\begin{array}{c}\mathrm{MPF} \\
3 \times \mathrm{SSC}\end{array}$ & $\begin{array}{c}\mathrm{MPF} \\
6 \times \mathrm{SSC}\end{array}$ \\
\hline "Pathogens" & $\begin{array}{l}\text { bataviae } \\
\text { javanica }\end{array}$ & $\begin{array}{r}100 \\
13\end{array}$ & $\begin{array}{l}100 \\
41.7\end{array}$ & $\begin{array}{l}100 \\
48.8\end{array}$ & $\begin{array}{l}0 \\
6\end{array}$ & $\begin{array}{r}10.2 \\
8.9\end{array}$ & $\begin{array}{l}4.8 \\
4.0\end{array}$ \\
\hline "Saprophy tes" & $\begin{array}{l}\text { patoc } \\
\text { codice }\end{array}$ & & $\begin{array}{l}7.3 \\
4.6\end{array}$ & $\begin{array}{l}4.8 \\
8.7\end{array}$ & $\begin{array}{c}100 \\
19.0\end{array}$ & $\begin{array}{c}100 \\
29.0\end{array}$ & $\begin{array}{l}100 \\
42.7\end{array}$ \\
\hline
\end{tabular}

${ }^{a}$ Data from Haapala et al. (7). 
TABLE 3. Characteristics of leptospiral DNA duplex formation in agar matrix under variable concentrations of SSC incubation media

\begin{tabular}{|c|c|c|c|c|c|c|c|c|c|c|}
\hline \multirow[b]{2}{*}{$\begin{array}{l}\text { Serotype } \\
\text { radio- } \\
\text { active } \\
\text { DNA }\end{array}$} & \multirow[b]{2}{*}{$\begin{array}{c}\text { Serotype } \\
\text { immobilized } \\
\text { DNA }\end{array}$} & \multicolumn{3}{|c|}{$2 \times \mathrm{SSC}$} & \multicolumn{3}{|c|}{$3 \times \mathrm{SSC}$} & \multicolumn{3}{|c|}{$6 \times$ SSC } \\
\hline & & $\begin{array}{l}\text { Bind- } \\
\text { ing } \\
(\%)\end{array}$ & $\begin{array}{c}\mathrm{E}_{\mathrm{m}}^{b} \\
(\mathrm{C})\end{array}$ & $\begin{array}{l}\text { Homol- } \\
\text { ogy } \\
(\%)\end{array}$ & $\begin{array}{l}\text { Bind- } \\
\text { ing } \\
(\%)\end{array}$ & $\mathrm{E}_{(\mathrm{C})}^{b}$ & $\begin{array}{l}\text { Homol- } \\
\text { ogy } \\
(\%)\end{array}$ & $\begin{array}{l}\text { Bind- } \\
\text { ing } \\
(\%)\end{array}$ & $\begin{array}{l}E_{m}^{b} \\
(C)\end{array}$ & $\begin{array}{c}\text { Homol- } \\
\text { ogy } \\
(\%)\end{array}$ \\
\hline bataviae* & $\begin{array}{l}\text { bataviae } \\
\text { icterohaemor- } \\
\quad \text { rhagiae } \\
\text { javanica }\end{array}$ & 42.2 & $\begin{array}{l}65.8 \\
63.2 \\
55.1\end{array}$ & $\begin{array}{l}100 \\
92.4 \\
\\
30.7\end{array}$ & 44.9 & $\begin{array}{l}65.5 \\
62.6 \\
\\
54.5\end{array}$ & $\begin{array}{l}100 \\
102 \\
41.0\end{array}$ & 52.9 & $\begin{array}{l}65.7 \\
62.2 \\
\\
54.6\end{array}$ & $\begin{array}{c}100 \\
98.7 \\
\\
50.2\end{array}$ \\
\hline ranarum * & $\begin{array}{l}\text { ranarum } \\
\text { bataviae } \\
\text { javanica }\end{array}$ & 52.8 & $\begin{array}{l}67.0 \\
53.7 \\
54.4\end{array}$ & $\begin{array}{l}100 \\
62.6 \\
40.9\end{array}$ & & & & & & \\
\hline patoc* & $\begin{array}{l}\text { patoc } \\
\text { codice } \\
\text { A- } 183^{a}\end{array}$ & 46.6 & $\begin{array}{l}68.1 \\
56.7 \\
57.5\end{array}$ & $\begin{array}{l}100 \\
20.5 \\
15.9\end{array}$ & 57.0 & $\begin{array}{l}67.7 \\
55.9 \\
56.3\end{array}$ & $\begin{array}{r}100 \\
24.5 \\
26.8\end{array}$ & 61.9 & $\begin{array}{l}68.5 \\
55.2 \\
56.6\end{array}$ & $\begin{array}{r}100 \\
31.2 \\
28.4\end{array}$ \\
\hline Turtle A-183* & $\begin{array}{l}\text { A-183 } \\
\text { patoc } \\
\text { codice }\end{array}$ & 24.9 & $\begin{array}{l}67.0 \\
57.0 \\
59.4\end{array}$ & $\begin{array}{l}100 \\
40.3 \\
50.1\end{array}$ & & & & & & \\
\hline illini* & illini & 23.3 & 68.7 & 100 & & & & & & \\
\hline
\end{tabular}

${ }^{a}$ The serotype of this strain has not been determined.

${ }^{b} \mathrm{E}_{\mathbf{m}}$, Thermal elution median.

there were sharply delineated groups with $70 \%$ or greater relative homology within complexes of obviously related organisms but less than $13 \%$ relative binding between strains of these different complexes. With little exception, increasing the salt concentration of the solution in which annealing took place appeared to induce greater binding among DNA of partial homology. This was especially striking when we compared work previously performed in $2 \mathrm{X}$ SSC in agar columns (Table 2; reference 7). Thus, the radioactive bataviae DNA fragments had apparent comparative homologies of $13 \%$ in $2 \times \mathrm{SSC}, 41.7 \%$ in $3 \times \mathrm{SSC}$, and $48.8 \%$ in 6 $X$ SSC with the immobilized javanica DNA. Similarly, the patoc $\mathrm{DNA}^{*}$ appeared to have homologies of $19 \%$ in $2 \times$ SSC, $29 \%$ in $3 \times$ SSC, and $42.7 \%$ in $6 \times$ SSC with the immobilized codice DNA. Increase in DNA binding under increased salt concentration did not occur between DNA from organisms which were definitely not genetically related (e.g., the bataviae DNA* and Proteus mirabilis DNA, Table 1).

This increased retention of DNA* raised two important questions: (i) did the salt actually increase DNA annealing, or (ii) was there a salt effect on the MPF which indirectly affected DNA retention on the filters? To solve these questions, the three salt concentrations were used to anneal DNA in agar matrices (Table 3). The results were then compared to those obtained on membrane filters (Table 1) and were similar.

Figure 1 shows the affect of temperature and salt concentration during the annealing process on the subsequent elution of DNA* from the homologous bataviae DNA. The elution profiles illustrated a trend whereby, regardless of salt concentration, as the temperature of incubation increased, the total amounts of duplexed DNA increased up to a point (65 $\mathrm{C}$ incubation) where two specific elution peaks were observed. At higher incubation temperatures, annealing conditions were more restrictive, resulting in less binding and a series of erratic peaks at the higher elution temperatures. Nonetheless, the elution profiles were indicative of a group of DNA within the species which preferentially bound at high salt concentrations and eluted at low temperatures. Whether this was preferential binding of DNA which was mismatched, damaged, or a unique segment is not known. In our tests, the incubation temperature for optimal annealing appeared to be $65 \mathrm{C}$. When other serotypes or unrelated species were compared to the bataviae DNA (Fig. 2), nonspecific aggregation of DNA was appropriately ruled 

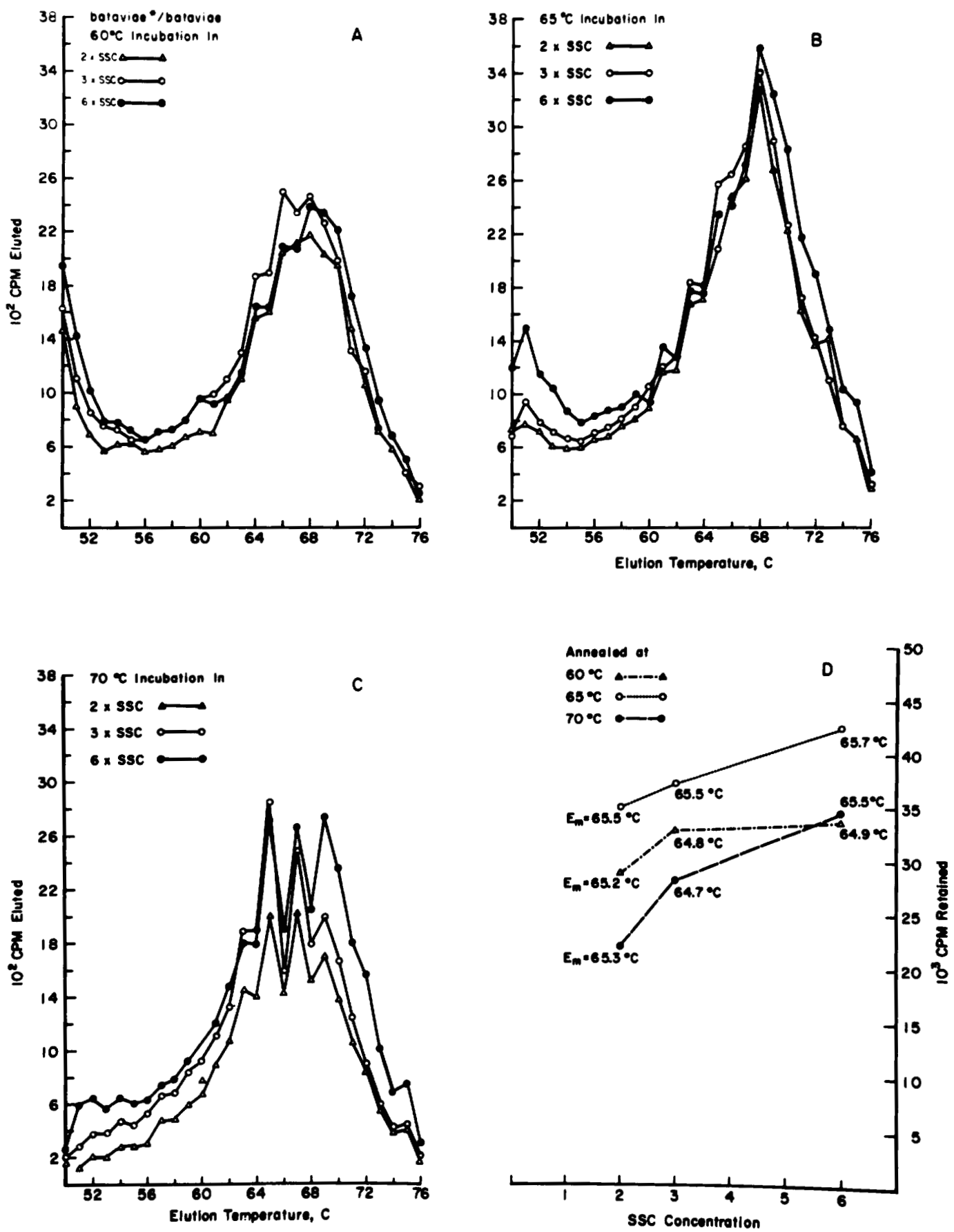

FIG. 1. Comparison of elution profiles of bataviae DNA* with agar-embedded homologous DNA in incubation fluids of different concentrations. Annealing temperatures were $(A) 60 C$, (B) $65 C$, and (C) $70 C$. (D) Characteristics derived from the elution profiles $A, B$, and $C$. Elution medians and total counts per minute bound at different salt concentrations. 

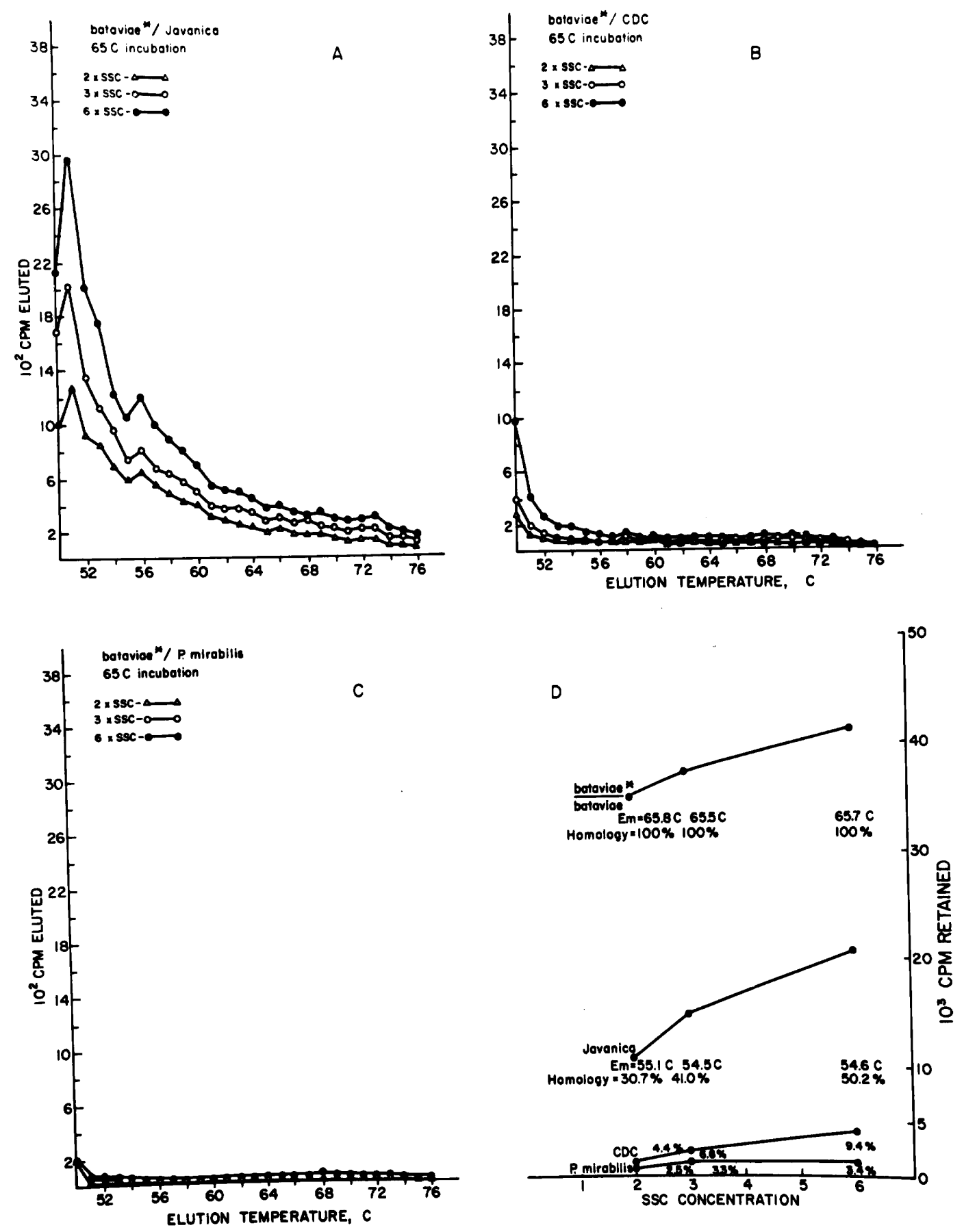

FIG. 2. Comparison of elution profiles of bataviae $D N A$ * incubated at $65 \mathrm{C}$ with agar-embedded heterologous $D N A$ in incubation fluids of varying salt concentrations. (A) bataviae $D N A{ }^{*}$ tested against javanica DNA, (B) bataviae $D N A{ }^{*}$ tested against codice $C D C D N A,(C)$ bataviae $D N A{ }^{*}$ tested against P. mirabilis $D N A,(D)$ characteristics derived from the elution profiles $A, B$, and $C$. Elution medians, percent homology, and total counts per minute bound at different salt concentrations. 
out (Fig. 2C and D). The high salt concentrations obviously encouraged greater annealing of partially related DNA sequences (Fig. 2 A, B, and D) but not between the bataviae DNA and obviously unrelated sources (Fig. 2C and D).

These affects were also studied on duplexes formed by the bataviae DNA* and a genetically closely-related strain, icterohaemorrhagiae RGA.

The elution profile of the bataviae DNA* annealed to the DNA of the RGA strain is very similar to the homologous reaction of the bataviae DNA (Fig. 1B). If anything, the initially eluted peak (Fig. 3A) was more pronounced. When the reaction was repeated and elution was examined at lower wash temperatures (Fig. 3B), there was an obvious elution of $\mathrm{DNA}^{*}$ at the lower temperatures but not the distinct peak which occurred when the washing began at $50 \mathrm{C}$.

In contrast, when the homologous DNA from serotype patoc was annealed at $65 \mathrm{C}$ (this was the compromise temperature for organisms having DNA of 36 to $39 \% \mathrm{G}+\mathrm{C}$ ), the amount of DNA* which eluted at low temperatures from a homologous duplex was negligible (Fig. 4A). Low-temperature elution of the patoc
DNA* apparently only occurred with duplexes formed with genetically heterologous but distinctly related strains.

The heterologous reaction of the patoc DNA*/codice DNA (Fig. 4B) was further investigated at very low elution temperatures (Fig. 4C). It was plain to see that small amounts of the patoc DNA* which annealed had clung to the codice DNA with great tenacity over a wide temperature range.

A number of strains which showed partial genetic homology were examined at varied salt concentrations in the agar columns. There was no doubt that the total bound DNA* increased with increasing salt concentration, but the thermal elution median $\left(E_{m}\right)$ remained relatively stable in the homologous reaction. As might be expected, the $E_{m}$ drops just slightly in the heterologous reactions as the salt concentration increases.

When all the results were assembled and compared, it was apparent that the Denhardt technique, as well as the agar-column method, provided a means of distinguishing genetically distinct strains or, under modified salt conditions, of emphasizing certain partial homologies. From Table 1 the almost negligible DNA
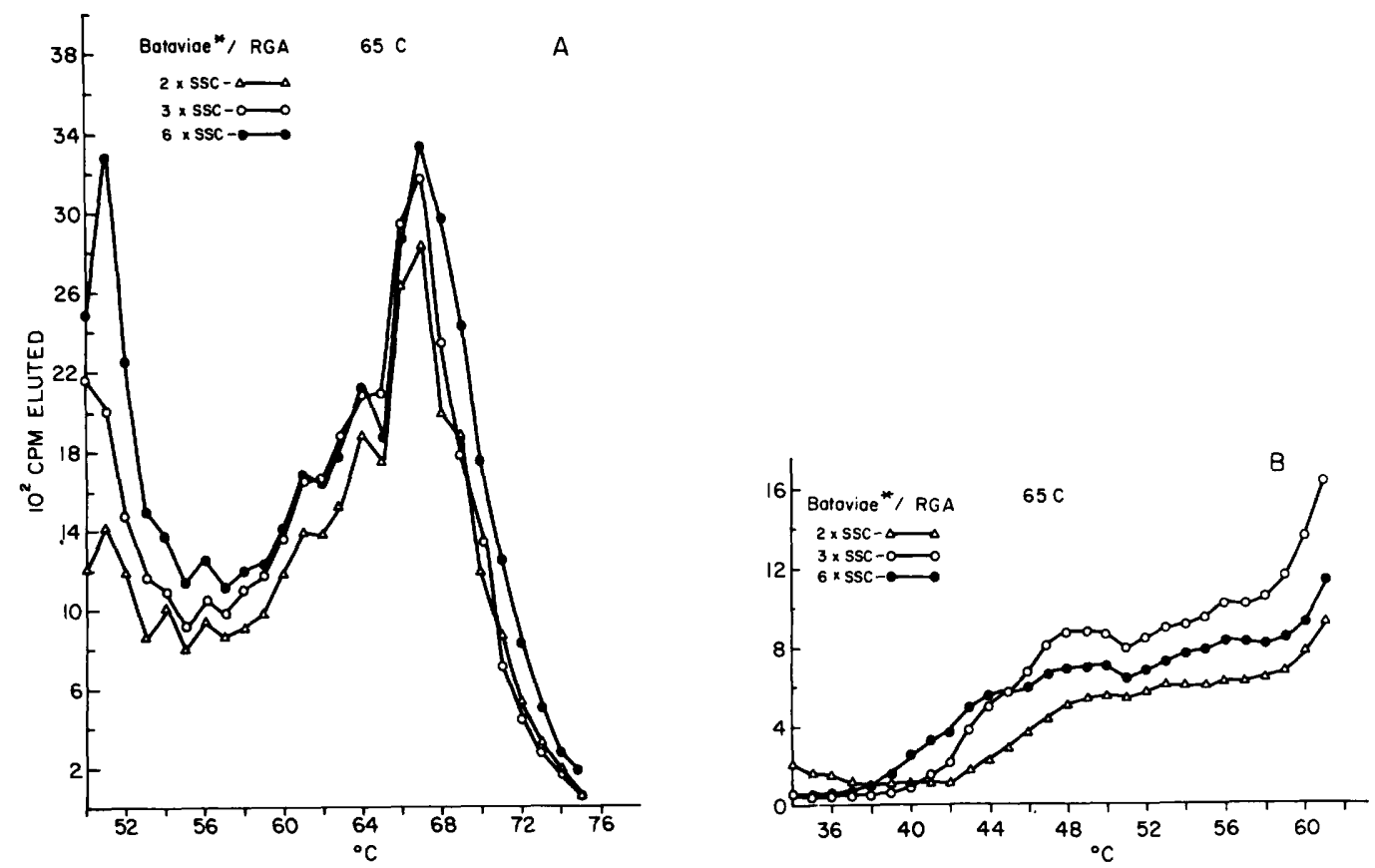

FIG. 3. Elution profile of bataviae DNA* incubated at $65 \mathrm{C}$ with icterohaemorrhagiae RGA DNA embedded in agar. Incubation fluids were varied as shown in figures. (A) Elution profile between $50 \mathrm{C}$ and $75 \mathrm{C}$. (B) Elution profile between $34 \mathrm{C}$ and $60 \mathrm{C}$. 

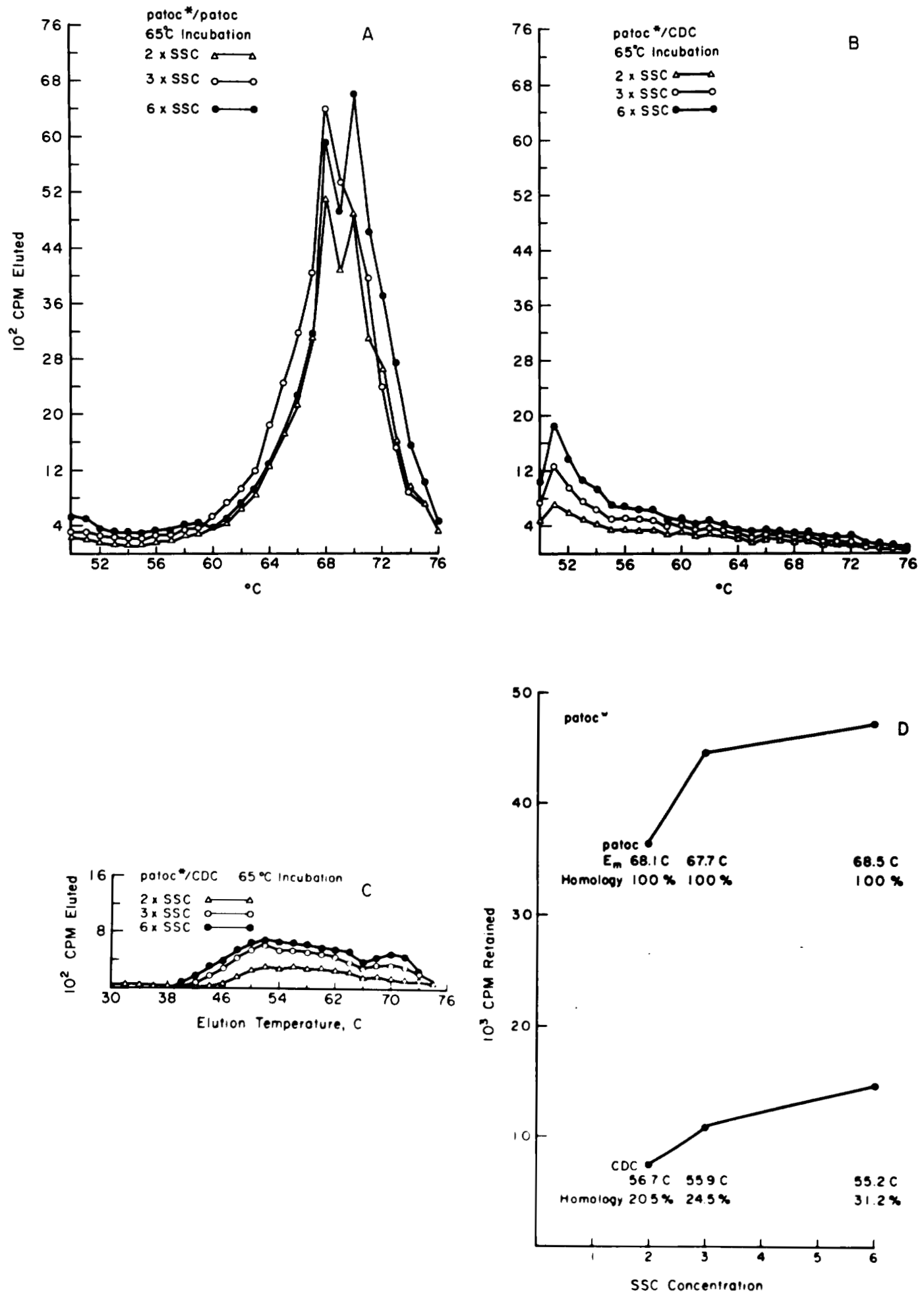

FIG. 4. Elution profiles of patoc DNA* incubated at $65 \mathrm{C}$ with homologous and heterologous agar-embedded $D N A$ under varying salt concentrations. $(A)$ patoc $D N A *$ tested against patoc DNA, (B) patoc DNA* tested against codice $C D C D N A$. Elution profile between $50 C$ and $76 C$. (C) patoc DNA ${ }^{*}$ tested against codice $C D C$ $D N A$. Elution profile between $30 C$ and $75 C$. (D) Characteristics derived from the elution profiles $A$ and $B$. The elution medians, percent homology, and total counts per minute bound at different salt concentrations. 
annealing of the pathogenic representatives (bataviae and javanica) with the saprophytic strains of either patoc or codice reflects the great genetic gulf between strains of the two major complexes, whereas Table 3 presents data which emphasizes the partial homologies of groups within the complexes. These data were summarized in Table 4.

Strain 3055 (serotype illini) appeared to have distinct nucleotide sequences and may represent a new "complex." Its DNA had little complementarity with DNA* from strains of bataviae, javanica, ranarum, patoc, codice, or A-183. The DNA annealing patterns of the icterohaemorrhagiae strain were indistinguishable from that of the serotype bataviae strain. This was confirmed in thermal-elution profiles using the bataviae DNA* and bound icterohaemorrhagiae RGA DNA (Fig. 3). Similarly, the muenchen strain appeared to have the same nucleotide sequence as the reference bataviae strain. These findings negated the usefulness of DAP as a differentiating character for genetic groups (9).
Among other pathogenic strains, partial homologies were demonstrated by immobilized DNA from strains of ranarum and kabura against the reference strains of bataviae and javanica DNA*. Strain Turtle A-183 had partial genetic homology with the two representative strains of the biflexa genetic group (Tables 1 and 3 ).

The genetic interrelatedness of the illini and ranarum strains and Turtle A-183, with each other and with the representative strains of the two pathogenic and two saprophytic genetic groups (Table 1), was reexamined by annealing DNA in agar columns $(2 \times$ SSC incubation fluid). As mentioned before, this method provided generally acceptable stringent conditions for duplex formation, and the derived elution profiles gave a more definitive account of the relationships among the population of sheared DNA duplexes. These results were also listed in Table 3. The Turtle A-183 and Frog (ranarum) strains were found to be genetically distinct entities within their complex. The findings indicated the presence of 7 distinct

TABLE 4. Percent relative homology of leptospiral DNA of representative serotypes

\begin{tabular}{|c|c|c|c|c|c|c|c|c|}
\hline \multirow[b]{2}{*}{ Complex } & \multirow{2}{*}{$\begin{array}{c}\text { Serotype } \\
\text { radioactive } \\
\text { DNA }^{a}\end{array}$} & \multicolumn{7}{|c|}{ Percent homology with immobilized DNA from serotype } \\
\hline & & bataviae & javanica & ranarum & patoc & codice & A-183 & illini \\
\hline \multirow[t]{3}{*}{ "Pathogens" } & bataviae $* b$ & 100 & 41.7 & 31.9 & 7.3 & 4.6 & 8.7 & 2.8 \\
\hline & javanica $* b$ & 35.2 & 100 & 39.8 & 3.0 & 3.1 & 5.7 & 4.9 \\
\hline & ranarum $* c$ & 62.6 & 40.9 & 100 & 2.6 & 1.2 & 1.6 & 0.8 \\
\hline \multirow[t]{3}{*}{ "Saprophytes" } & patoc $^{* b}$ & 10.2 & 8.9 & 10.6 & 100 & 29.0 & 35.6 & 2.6 \\
\hline & codice $e^{* b}$ & 8.4 & 6.6 & 6.3 & 35.7 & 100 & 59.1 & 1.7 \\
\hline & Turtle A-183*c & 2.7 & 7.9 & 6.2 & 40.3 & 50.1 & 100 & 5.4 \\
\hline New & illini $^{* c}$ & 2.9 & 6.6 & 3.3 & 6.4 & 9.0 & 6.4 & 100 \\
\hline
\end{tabular}

${ }^{a}$ Nonrelated DNA binding with Proteus mirabilis ranged from 0.5 to $3.4 \%$ in agar matrix and from 1.8 to $3.6 \%$ on membrane filters.

$b$ DNA annealed on membrane filter in $3 \times$ SSC solvent.

$c$ DNA annealed on agar matrix in $2 \times$ SSC solvent.

TABLE 5. Phenotypic characteristics of genetically-distinct serotypes ${ }^{a}$

\begin{tabular}{l|c|c|c|c|c|c|c}
\hline \multirow{2}{*}{\multicolumn{1}{c|}{ Characteristic }} & \multicolumn{3}{c|}{ Pathogenic complex } & \multicolumn{3}{c|}{ Saprophy tic complex } & illini $^{b}$ \\
\cline { 2 - 8 } & bataviae & javanica & ranarum & patoc & codice & A-183 & illini \\
\hline "Pathogenic" & + & + & $?$ & - & - & $?$ & $?$ \\
Resistance to AZA & $\mathrm{S}$ & $\mathrm{S}$ & $\mathrm{S}$ & $\mathrm{R}$ & $\mathrm{R}$ & $\mathrm{R}$ & $\mathrm{R}$ \\
Resistance to Cu ions & $\mathrm{S}$ & $\mathrm{S}$ & $\mathrm{S}$ & $\mathrm{R}$ & $\mathrm{R}$ & $\mathrm{R}$ & $\mathrm{R}$ \\
Resistance to NaHCO & $\mathrm{S}$ & $\mathrm{S}$ & $\mathrm{S}$ & $\mathrm{R}$ & $\mathrm{R}$ & $\mathrm{R}$ & \\
Growth at 13 C & - & - & + & + & + & & \\
Lipase & + & - & & + & + & + & $53.0^{c}$ \\
\% & 35.3 & 39.9 & 41.2 & 38.3 & 38.0 & 36.0 & 53.0 \\
\hline
\end{tabular}

${ }^{a}$ Abbreviations: $\mathrm{R}$, resistant; $\mathrm{S}$, sensitive; AZA, 8-azaguanine.

$b$ Ritchie et al. (12) demonstrated a phage in strain 3055 of seroty pe illini.

c Apparent base composition derived from buoyant-density data. 
genetic groups of leptospiras which could be assembled into 3 major "complexes" on the basis of DNA relatedness. Between complexes, strains have little or no demonstrable genetic relatedness. Two of the three complexes could each be segregated into groups of strains which have partial DNA homologies. Complexes of pathogenic and saprophytic leptospiras were each comprised of 3 genetic groups. A third complex comprised the strain of serotype illini. The relatedness of the kabura strain to other pathogenic genetic types was not determined. Table 4 was designed to bring together the information in both Tables 1 and 3 , whereas the phenotypic characteristics in Table 5 were assembled because of the data derived from these DNA tests. The DNA nucleotide base composition of illini strain 3055 was particularly striking and may reflect the presence of a phage genome (12) or some other condition. This strain requires a DNA examination by other definitive methods. We also concluded that the percent $G+C$ of DNA could not be correlated with pathogenicity.

It is interesting that 3 or 4 strains which were selected for further genetic studies because of their unusual origin or unusual phenotypic attributes proved to be genetically distinct. The characters which prompted their selection may in combination suffice to distinguish strains between, but not within, "complexes."

\section{ACKNOWLEDGMENTS}

We thank L. B. Evans and B. T. Mitzner for excellent technical assistance.

\section{LITERATURE CITED}

1. Babudieri, B. 1972. Systematics of a leptospira strain isolated from a frog. Experientia 28: 1252-1253.

2. DeLey, J., and R. Tijtgat. 1970. Evaluation of membrane filter methods for DNA-DNA hybridization. Antonie van Leeuwenhoek J. Microbiol. Serol. 36:461-474.

3. Denhardt, D. T. 1966. A membrane-filter technique for the detection of complementary DNA Biochem. Biophys. Res. Commun. 23:641-646.

4. Diesch, S. L., W. F. McCullock, J. L. Brown, and H. C. Ellinghausen. 1966. Leptospires isolated from frog kidneys. Nature (London) 209: 939-941.

5. Ellinghausen, H. C., Jr. 1968. Cultural and biochemical characteristics of a leptospire from frog kidney. Bull. Wildlife Dis. Ass. 4:41-50.

6. Gillespie, D., and S. Spiegelman. 1965. A quantitative assay for DNA-RNA hybrids with DNA immobilized on a membrane. J. Mol Biol. 12: 829-842.

7. Haapala, D. K., M. Rogul, L. B. Evans, and A. D. Alexander. 1969. Deoxyribonucleic and base composition and homology studies of Leptospira. J. Bacteriol. 98:421-428.

8. Hudson, J. B. 1971. The fixation and retention of viral and mammalian deoxyribonucleic acids on nitrocellulose filters. Can. J. Biochem. 49: 631-636.

9. Johnson, R. C., and V. G. Harris. 1968. Purine analogue sensitivity and lipase activity of leptospires. Appl. Microbiol. 16:1584-1590.

10. Marmur, J. 1961. A procedure for the isolation of deoxyribonucleic acid from micro-organisms. J. Mol. Biol. 3:208-218.

11. Nardelli, M. G., and B. Babudieri. 1972. Studio sistematico di 20 ceppi di leptospire acquicole. Ann. Inst. Super. Sanita. 8:114-121.

12. Ritchie, A. E., and H. C. Ellinghausen. 1969. p. 228-229. In J. Arcenaux (ed.). Proc. ElectronMicroscopy Soc. Amer., Baton Rouge, La., Claiton.

13. Rogul, M., J. J. Brendle, D. K. Haapala, and A. D. Alexander. 1970. Nucleic acid similarities among Pseudomonas pseudomallei, Pseudomonas multivorans and Actinobacillus mallei. J. Bacteriol. 101:827-835.

14. Schildkraut, C. L., J. Marmur, and P. Doty. 1962. Determination of the base composition of deoxyribonucleic acid from its buoyant density of $\mathrm{CsCl}$. J. Mol. Biol. 4:430-443.

15. Tripathy, D. N., and L. E. Hanson. 1973. Studies of Leptospira illini, strain 3055: pathogenicity for different animals. Amer. J. Vet. Res. 34: 557-562.

16. Tripathy, D. N., and L. E. Hanson' 1973. Studies of Leptospira illini, strain 3055: immunological and serological determinations. Amer. J. Vet. Res. 34:563-565.

17. Vera, H. D., and M. Dermoff. 1970. Culture media, p. 650. In J. E. Blair, E. H. Lennette, and J. P. Truant (ed.). Manual of clinical microbiology. American Society for Microbiology, Bethesda, Md.

18. World Health Organization. 1967. Current problems in leptospirosis research: report of a WHO expert group, p. 32. World Health Organ. Tech. Rep. Sir. No. 380 , Geneva. 